\title{
New editorial office
}

\author{
Kazusato Ohshima
}

Published online: 29 November 2011

(c) The Phytopathological Society of Japan and Springer 2011

It is an immense pleasure and honour to take over as the Editor of Journal of General Plant Pathology as of January 1, 2012. The baton has been passed to me and my colleagues from the former editorial office led by Prof Tetsuro Okuno (Kyoto University), who has done so much to develop the journal.

The editorial system and publication format of the Journal of General Plant Pathology have undergone various changes over the last 5 years. The Journal of General Plant Pathology launched an online submission and tracking system (https://www.editorialmanager.com/jgpp/) in April 2007. The system substantially reduces the editorial processing and review time and should result in a reduction of overall publication time. I am happy to announce that the impact factor of the Journal of General Plant Pathology, which was released for the first time in 2011, was 0.687. This results from the work of earlier editors and their colleagues, most of whom are members of the Phytopathological Society of Japan.

The Journal of General Plant Pathology covers all areas of plant pathology: plant diseases and their control, including pathogen characterization, identification of pathogens, disease physiology and biochemistry, molecular biology, morphology and ultrastructure, genetics, disease transmission, ecology and epidemiology, evolution, chemical and biological control, disease assessment, and other topics relevant to plant pathological disorders. The journal is published every 2 months and welcomes the submission of manuscripts from all areas of plant pathology and related topics.

The Phytopathological Society of Japan was founded in 1916 to promote and spread knowledge of plant diseases and their control in Japan, but has grown to become an international society. The society is proud to be one of the oldest leading academic societies in the field of agricultural science in Japan. In August 2011, our society had 1385 members including 16 overseas members, and in addition 271 student members. Part of the internationalization process has been the launch of the Journal of General Plant Pathology, the main journal of the Phytopathological Society of Japan. As my colleagues and I assume editorial responsibility for the Journal of General Plant Pathology, we hope to continue its remarkable history while continuing to improve the journal, fostering and developing the science of plant pathology and related areas by providing information that is accurate, reliable, and beneficial.

I look forward to working with both the Associate Editors inside and outside of Japan, and the editorial office over the next 2 years. We intend to develop the journal and to maintain its position as a world leading publication in the field of plant pathology.

I cordially invite you to submit your research papers to the Journal of General Plant Pathology.

Editor-in-chief of the Journal of General Plant Pathology Kazusato Ohshima
K. Ohshima ( $\square)$

Laboratory of Plant Virology, Department of Applied Biological

Sciences, Faculty of Agriculture, Saga University,

Saga 840-8502, Japan

e-mail: ohshimak@cc.saga-u.ac.jp 